\title{
PENGARUH PERSEPSI HARGA, PROMOSI, DAN KUALITAS PELAYANAN TERHADAP KEPUASAN DAN DAMPAKNYA TERHADAP LOYALITAS KONSUMEN
}

\author{
I Made Adi Juniantara ${ }^{1}$ \\ Tjokorda Gde Raka Sukawati ${ }^{2}$
}

\author{
${ }^{1,2}$ Fakultas Ekonomi dan Bisnis Universitas Udayana, Bali, Indonesia \\ 1e-mail: imadeadijuniantara@gmail.com
}

\begin{abstract}
ABSTRAK
Di Denpasar aplikasi penyedia jasa transportasi berbasis online mengalami persaingan yang sangat ketat demi mendapatkan keuntungan yang besar. Di wilayah Denpasar sendiri sudah beroperasi tiga aplikasi penyedia jasa berbasis Online yaitu Uber, Gojek dan Grab.Pada penelitian ini jenis jasa transportasi online yang akan dipilih adalah UberX. Lokasi penelitian dilakukan di kota Denpasar. Jumlah sampel yang digunakan sebanyak 133 responden, penentuan sampel menggunakan metode non-probability sampling dengan teknik purposive sampling. Metode pengumpulan data yang digunakan yaitu kuesioner dengan teknik analisis jalur (path analysis). Hasil penelitian menemukan bahwa persepsi harga berpengaruh positif dan signifikan terhadap kepuasan, promosi berpengaruh positif dan signifikan terhadap kepuasan, kualitas pelayanan berpengaruh positif dan signifikan terhadap kepuasan, dan kepuasan konsumen berpengaruh positif dan signifikan terhadap loyalitas konsumen. Hal ini menunjukan bahwa semakin baik persepsi konsumen terhadap harga, promosi dan kualitas pelayanan yang diberikan maka akan meningkatkan kepuasan dan loyalitas pelanggan UberX.
\end{abstract}

Kata Kunci: persepsi harga, promosi, kualitas pelayanan, kepuasan, loyalitas

\begin{abstract}
In Denpasar the application of online-based transport service providers experienced a very tight competition in order to get big profits. In the area of Denpasar itself has been operating three online service provider-based services such as Uber, Gojek and Grab. This research type of online transportation services to be selected is UberX. The research location was conducted in Denpasar city. The number of samples used were 133 respondents, sample determination using non-probability sampling method with purposive sampling technique. Data collection method used is questionnaire with path analysis technique (path analysis). The result of the research found that price perception have positive and significant influence to satisfaction, promotion have positive and significant effect to satisfaction, service quality have positive and significant effect to satisfaction, and consumer satisfaction have positive and significant influence to consumer loyalty. This shows that the better the consumer perception of price, promotion and quality of service provided will increase customer satisfaction and loyalty UberX.
\end{abstract}

Keywords: price perception, promotion, service quality, satisfaction, loyalty 
I Made Adi Juniantara, Pengaruh Persepsi Harga, Promosi...

\section{PENDAHULUAN}

Aplikasi penyedia jasa transportasi berbasis online mengalami persaingan yang sangat ketat demi mendapatkan keuntungan yang besar terjadi di Kota Denpasar. Beroperasi tiga aplikasi penyedia jasa berbasis Online yaitu Uber, Gojek dan Grab. Aplikasi tersebut memiliki produk tersendiri yaitu Uber dengan UberX, Gojek dengan Go Car dan Grab dengan Grab Car. Masing-masing penyedia jasa transportasi online menerapkan sistem tarif/harga yang berbeda. UberX menawarkan tarif dengan sistem tarif dasar, biaya perkilometer dan tarif menunggu. Sedangkan Grab Car menawarkan tarif datar sesuai dengan yang tertera di aplikasi sama halnya dengan Go Car. Ketiga aplikasi tersebut juga menawarkan metode pembayaran yang berbeda-beda. Uber menawarkan pilihan pembayran secara tunai dan non tunai (kartu debit/kredit) sedangkan aplikasi Grab Car menawarkan pembayaran secara tunai dan non tunai (GrabPay) yang bisa di Top Up menggunakan semua jenis Bank. Go Car menawarkan metode pempayaran secara tunai dan non tunai (Go Pay) dengan sumber dana bisa berasal dari kartu kredit dan kartu debit aneka Bank.

Manusia sebagai mahluk sosial mempunyai banyak kebutuhan yang harus dipenuhi untuk kesejahteraan hidupnya. Kebutuhan tersebut dimungkinkan tidak dapat terpenuhi dalam satu lokasi. Oleh karena itu manusia memerlukan transportasi untuk melakukan perpindahan orang dan/atau barang dari satu tempat ketempat yang lain dengan menggunakan kendaraan. Harga, promosi dan kualitas pelayanan merupakan hal yang sangat diperhatikan oleh konsumen dalam kepuasannya menggunakan sebuah produk/jasa. 
Di tengah persaingan yang semakin ketat Uber harus mengetahui kebutuhan dan keinginan konsumen. Kebutuhan merupakan keadaan merasa tidak memiliki kepuasan dasar dan bersifat naluriah sedangkan keinginan adalah hasrat akan pemuas tertentu dari kebutuhan tersebut, sehingga keinginan merupakan kebutuhan buatan yaitu kebutuhan yang dibentuk oleh lingkungan hidupnya. Keinginan terhadap suatu produk yang didukung dengan kemampuan serta ketersediaan untuk membelinya.

Promosi yang dilakukan oleh masing-masing perusahaan membuat ketertarikan konsumen untuk menggunakan produk/jasa yang ditawarkan dengan memberikan potongan harga, diskon, kode undangan dan perjalanan gratis. Dimana perusahaan Uber menawarkan promosi free ride sampai dengan Rp 20,000 untuk dua kali perjalanan pertama dengan menggunakan aplikasi Uber dan bisa menggunakan kode undangan untuk mengundang teman bergabung sebagai pengguna baru. Sedangkan perusahaan Grab memberikan kode promo yang bisa digunakan untuk potongan perjalanan seperti kode promo LEBIHIRIT (berlaku 1 Januari - 28 Februari 2018) yang ditawarkan untuk produk mobil. Gojek juga menawarkan promo khusus untuk pengguna yang melakukan pembayaran menggunakan sistem pembayaran non-tunai Go-Pay dan memberikan potongan $20 \%$ untuk semua pengguna. Promosi yang ditawarkan oleh masing-masing perusahaan bertujuan untuk memenangkan persaingan.

Agar berhasil dalam memenangkan persaingan, setiap perusahaan perlu memperhatikan kondisi lingkungan internal dan eksternalnya, ini akan menjadi 
I Made Adi Juniantara, Pengaruh Persepsi Harga, Promosi...

dasar dalam pengambilan strategi yang harus diterapkan untuk menghadapi persaingan. Strategi yang diterapkan perusahaan bisa saja berbeda karena kondisi yang berbeda, kemudian dicocokkan dengan kebutuhan saat itu sehingga bisa menjawab tantangan persaingan yang semakin tinggi serta tetap memperhatikan kebutuhan konsumen. Strategi mempertahankan konsumen bertujuan untuk membangun loyalitas konsumen dengan cara memuaskan konsumen, yang kemudian akan membeli jasa-jasa tambahan yang disediakan perusahaan dan tidak mungkin beralih kepada pihak pesaing.

Suprapti (2010:285), menyatakan kepuasan pelanggan merupakan sikap keseluruhan yang diperlihatkan oleh pelanggan terhadap suatu produk setelah menggunakan atau mengkonsumsi produk itu. Dilihat dari perspektif manajerial, mempertahankan dan meningkatkan kepuasan pelanggan merupakan hal yang sangat penting. Menurut Irawan (2008:37), kepuasan pelangganditentukan oleh persepsi pelanggan atas performance produk atau jasa dalam memenuhi harapan pelanggan. Irawan (2008:37), berpendapat ada lima faktor utama penentu kepuasan pelanggan yaitu: kualitas produk, harga, service quality, emotional factor, dan biaya.

Loyalitas merupakan suatu komitmen yang mendalam untuk membeli kembali atau berlangganan suatu produk atau jasa secara konsisten dimasa yang akan datang sehingga dapat menyebabkan pengulangan pembelian menurut Endang (2013). Menurut Agyapong (2011) kualitas pelayanan telah ditemukan di dalam literatur unruk menjadi alat yang kompetitif bagi banyak perusahaan. Hal ini menjadi strategi bagi perusahaan yang memiliki ciri khas atau karakter yang 
kuat pada produk dan pelayanannya sehingga dapat memuaskan kebutuhan konsumennya.

Pada penelitian kali ini jenis jasa transportasi online yang akan dipilih adalah UberX karena peneliti tertarik untuk mengetahui pengaruh harga, promosi, kualitas pelayanan terhadap kepuasan konsumen dan menyebabkan loyalitas konsumen meningkat. Lokasi penelitian dilakukan di Denpasar karena pengguna UberX di Kota Denpasar masih tergolong sedikit, maka peneliti tertarik untuk mengetahui pengaruh harga, promosi, kualitas pelayanan yang di inginkan oleh pengguna UberX di kota Denpasar.

Uber adalah perusahaan rintisan dan perusahaan jaringan transportasi asal San Francisco, California. Uber menciptakan aplikasi penyedia transportasi yang menghubungkan penumpang dengan pengemudi/sopir serta layanan tumpangan. Uber mengatur layanan penjemputan di berbagai kota di seluruh dunia. Mobil dapat dipesan dengan menggunakan smartphone melalui aplikasi. Uber masuk ke Indonesia pada 13 Agustus 2014. Awalnya, Uber baru melayani pelanggannya di kawasan Ibu Kota Jakarta dan meluas ke beberapa kota di Indonesia yang tersebar di 7 pulau di Indonesia yaitu: Jawa, Bali, Lombok, Sumatera, Batam, Kalimantan dan Sulawesi. Uber masuk ke Pulau Bali di awal maret 2015 dan beroperasi di Denpasar.

Persepsi konsumen terhadap suatu harga dapat memengaruhi keputusan dalam membeli atau menggunakan suatu produk sehingga suatu perusahaan harus mampu memberikan persepsi yang baik terhadap produk atau jasa yang mereka jual. Menurut Jiang (2015) persepsi adalah suatu proses seorang individu dalam 
I Made Adi Juniantara, Pengaruh Persepsi Harga, Promosi...

menyeleksi, mengorganisasikan, dan menterjemahkan stimulus-stimulus informasi yang datang menjadi suatu gambaran yang menyeluruh. Persepsi mempunyai pengaruh yang sangat kuat bagi konsumen. Salah satu faktor yang berpengaruh terhadap konsumen yaitu persepsi akan harga. Kotler dan Keller (2012:439) menyatakan bahwa harga adalah sejumlah uang yang dibebankan atas suatu produk, atau jumlah dari nilai yang ditukar konsumen atas manfaat-manfaat karena memiliki atau menggunakan produk atau jasa tersebut.

Menurut Jiang dan Rosenblom (2015) harga merupakan satu-satunya unsur bauran pemasaran yang memberikan pemasukan atau pendapatan bagi perusahaan sedangkan ketiga unsur lainnya (Produk, Promosi dan Distribusi) menyebabkan timbulnya biaya. Harga merupakan satuan moneter atau ukuran lainnya (termasuk barang dan jasa lainnya) yang ditukarkan agar memperoleh hak kepemilikan atau penggunaan suatu barang atau jasa menurut Alam dan Norjaya (2010). Hasil penelitian Oosthuizen dan Spowart (2015) menyatakan bahwa konsumen menggunakan persepsi mereka terhadap kerelatifan harga sebagai jalan untuk merasakan nilai dari produk tersebut sehingga konsumen dapat menetukan niat mereka untuk membeli produk.

Perbedaan harga yang ditawarkan oleh perusahaan jasa transportasi berbasis online ini hampir memiliki kesamaan. Persaingan yang dilakukan oleh perusahaan-perusahaan transportasi online di Kota Denpasar yaitu dengan memenangkan biaya antar yang murah. Penerapan tarif yang membuat konsumen sangat memperhatikan faktor harga sebagai acuan untuk memilih transportasi.

Keputusan mengenai harga akan menentukan keberhasilan atau kegagalan 
bagi perusahaan. Harga merupakan dasar terbentuknya keuntungan sehingga seluruh perusahaan berusaha memaksimalkannya dengan pengembangan pasar. Permintaan pasar sebagian besar dipengaruhi oleh harga. Harga akan memberikan posisi yang kompetitif pada pasar.

Alma (2014) mendefinisikan harga sebagai nilai suatu barang yang dinyatakan dengan uang.. Menurut Tjiptono, (2008) produk-produk yang berkualitas sesuai dengan standart kualitas yang diinginkan oleh konsumen, dan harga produk yang ditawarkan sesuai dengan manfaat, sehingga konsumen lebih memilih tempat berbelanja, konsumen selalu merekomendasikan hal-hal yang baik tentang dan konsumen merasa senang jika berbelanja. Berdasarkan uraian diatas maka dapat dijelaskan bahwa harga adalah sejumlah uang (satuan moneter) yang diberikan atau dikorbankan oleh konsumen untuk mendapatkan produk atau jasa.

Ginting (2012:10) promosi adalah semua kegiatan perusahaan produsen untuk meningkatkan mutu produknya dan membujuk/merayu konsumen agar membeli produknya. Griffin dan Ronal, (2007:281) menyatakan promosi adalah komponen bauran pemasaran yang paling terlihat nyata yang mengacu pada teknik-teknik mengkomunikasikan informasi mengenai produk. Alat promosi terpenting mencangkup iklan, penjualan pribadi, promosi penjualan, dan hubungan masyarakat.

Endang (2013), bauran promosi adalah kombinasi lima alat utama yang terdiri dari periklanan, personal selling, publisitas, promosi penjualan dan pemasaran langsung. Promosi merupakan salah satu variabel yang terdapat dalam 
I Made Adi Juniantara, Pengaruh Persepsi Harga, Promosi...

bauran pemasaran yang memiliki peranan penting untuk mengkomunikasikan keberadaan dan nilai produk kepada calon pelanggan.

Di tengah persaingan yang semakin ketat Uber harus mengetahui kebutuhan dan keinginan konsumen. Kebutuhan merupakan keadaan merasa tidak memiliki kepuasan dasar dan bersifat naluriah sedangkan keinginan adalah hasrat akan pemuas tertentu dari kebutuhan tersebut, sehingga keinginan merupakan kebutuhan buatan yaitu kebutuhan yang dibentuk oleh lingkungan hidupnya. Keinginan terhadap suatu produk yang didukung dengan kemampuan serta ketersediaan untuk membelinya.

Menurut Setiyaningrum (2015:233) bauran promosi terdiri atas beberapa komponen utama, yaitu; 1) Iklan, 2) Penjualan pribadi (personal selling), 3) Promosi penjualan (sales promotion), 4) Hubungan masyarakat (public relations), 5) Publikasi. Iwan Dkk, (2008) menyatakan bauran promosi yang dilakukan perusahaan akan menciptakan suatu penilaian tersendiri pada pikiran konsumen sehingga penilaian konsumen terhadap promosi produk secara langsung maupun tidak langsung akan menciptakan loyalitas pelanggan terhadap suatu produk.

Aktivitas promosi merupakan usaha pemasaran yang memberikan berbagai upaya intensif jangka pendek untuk mendorong keinginan mencoba atau membeli suatu produk atau jasa seluruh kegiatan promosi bertujuan untuk mempengaruhi perilaku pembelian.

Menurut Tjiptono (2008:210) promosi adalah suatu bentuk komunikasi pemasaran yang merupakan aktivitas pemasaran yang berusaha menyebarkan informasi, mempengaruhi/ membujuk, dan/atau meningatkan pasar sasaran atas 
perusahaan dan produknya agar bersedia menerima, membeli, dan loyal pada produk yang ditawarkan perusahaan yang bersangkutan.

Menurut Bhuwana dan Sudiksa (2013) dan Oosthuizen (2015) kualitas pelayanan dipersepsikan baik dan memuaskan apabila jasa yang diterima atau dirasakan sesuai dengan yang diharapkan. Penelitian Widjajanti dan Ernawati (2012) menyatakan bahwa guna mengetahui apakah perusahaan sudah memberikan kualitas jasa yang sesuai dengan harapan konsumen maka perlu dievaluasi dari konsumennya. Indikator kualitas pelayanan yang digunakan dalam penelitian ini, Rangkuti (2006:29), yaitu: Tangibles, meliputi: fasilitas fisik, perlengkapan, pegawai/karyawan, dan sarana komunikasi. Reliability adalah kemampuan memberikan pelayanan yang dijanjikan dengan segera, akurat, dan memuaskan. Responsiveness yakni keinginan para staf dan karyawan untuk membantu pelanggan dan memberikan pelayanan dengan tanggap. Assurance (jaminan) adalah mencakup pengetahuan, kemampuan, kesopanan, dan sikap dapat dipercaya yang dimiliki para staf, bebas dari bahaya dan resiko atau keraguraguan. Emphaty, meliputi kemudahan dalam melakukan hubungan, komunikasi yang baik, perhatian pribadi, dan memahami kebutuhan pelanggan.

Menurut Tjiptono dan Chandra (2011:115), kualitas pelayanan memiliki hubungan yang erat dengan kepuasan pelanggan. Kualitas pelayanan memberikan dorongan kepada pelanggan untuk menjalin ikatan hubungan yang kuat dengan perusahaan. Dalam jangka panjang seperti ini memungkinkan peruasahaan untuk memahami dengan seksama harapan pelanggan serta kebutuhan pelanggan. Dengan demikan, perusahaan dapat meningkatkan kepuasan pelanggan dimana 
I Made Adi Juniantara, Pengaruh Persepsi Harga, Promosi...

perusahaan pengalaman memaksimumkan pelanggan dapat menciptakan kesetiaan atau loyalitas pelanggan kepada perusahaan yang memberikan kualitas memuaskan.

Menurut Tjiptono, (2008:118) kualitas merupakan suatu kondisi dinamis yang berpengaruh dengan produk, jasa, manusia, proses dan lingkungan yang memenuhi atau melebihi harapan. Dengan demikian, kualitas pelayanan dapat diartikan sebagai upaya pemenuhan kebutuhan dan keinginan konsumen serta ketepatan penyampaiannya dalam mengimbangi harapan konsumen.

Lupiyoadi, (2013) menyatakan bahwa salah satu yang mempengaruh tingkat loyalitas konsumen adalah kualitas pelayanan perusahaan perlu meningkatkan kualitas jasa untuk mengembangkan loyalitas pelanggannya, karena produk atau jasa yang berkualitas rendah akan menanggung risiko pelanggan tidak setia. Jika kualitas diperhatikan, maka loyalitas pelanggan akan lebih mudah diperoleh.

Herawati dkk. (2013) mengatakan bahwa jasa merupakan aktivitas, manfaat atau kepuasan yang ditawarkan kepada konsumen. Kualitas pelayanan yang baik mampu membuat konsumen untuk bertahan dan mau melakukan pembelian ulang.

Terciptanya kepuasan pelanggan dapat memberikan manfaat yang cukup besar, diantaranya adalah hubungan antara perusahaan dengan pelanggan menjadi harmonis dan terciptanya loyalitas pelanggan (Kurniasih, 2012). Menurut Rachmad, (2009) kepuasan nasabah ditentukan oleh kualitas produk dan layanan yang dikehendaki nasabah, sehingga jaminan kualitas menjadi perioritas utama bagi bank. Untuk kepuasan nasabah terhadap layanan, ada dua hal pokok yang saling berkaitan erat yaitu harapan nasabah terhadap kualitas Iayanan (expected 
quality) dan persepsi nasabah terhadap kualitas layanan (perceived quality). Nasabah selalu menilai suatu layanan yang diterima dibandingkan dengan apa yang diharapkan atau diinginkan.

Olorunniwo et al. (2010) dan Setiawan (2017), menghasilkan temuan tangible, responsiveness, knowledge dan recovery merupakan faktor-faktor yang mempengaruhi kepuasan konsumen. Faktor responsiveness dan knowledge merupakan faktor yang lebih tinggi pengaruhnya terhadap kepuasan konsumen dibandingkan faktor tangible dan recovery. Sedangkan faktor tangible merupakan faktor yang kurang penting dibandingkan dengan ketiga faktor lainnya

Menurut Kotler dan Keller (2009:175) menyatakan loyalitas/kesetiaan sebagai komitmen yang dipegang kuat untuk membeli lagi atau berlangganan lagi produk atau jasa tertentu dimasa depan meskipun ada pengaruh situasi dan usaha pemasaran yang berpotensi menyebabkan peralihan perilaku. Dengan demikian jika seorang pelanggan telah membeli dua atau tiga kali produk yang sama maka otomatis telah dimasukan sebagai pelanggan yang loyal Hermawan (2017:134)

Penelitian yang dilakukan oleh Nardiman dan Yasri (2013) Dari hasil penelitian diketahui bahwa Persepsi harga berpengaruh signifikan terhadap kepuasan nasabah Adira Finance di Kecamatan Kinali. Hal ini dipertegas dengan hasil dari penelitian yang di lakukan oleh Harjanto (2010) dan Ardhana (2010) yang menunjukan bahwa persepsi harga berpengaruh positif terhadap kepuasan pelanggan.

$\mathrm{H}_{1}$ : Persepsi harga berpengaruh positif dan signifikan terhadap kepuasan konsumen. 
I Made Adi Juniantara, Pengaruh Persepsi Harga, Promosi...

Penelitian yang dilakukan oleh Faradina dan Satrio (2016) Promosi berpengaruh signifikan dan positif terhadap kepuasan pelanggan pada Rumah Cantik Alamanda Surabaya. Selain itu dalam penelitian yang dilakukan oleh Tjahjaningsih (2013) Promosi berpengaruh positif signifikan terhadap kepuasan pelanggan, dimana Semakin tinggi promosi, maka akan semakin tinggi pula loyalitas pelanggan studi pada pelanggan Supermarket Carrefour Semarang. Hasil penelitian. Khan et al. (2012) memberikan hasil bahwa terdapat pengaruh positif antara promosi terhadap kepuasan pelanggan. Sehingga semakin banyak promosi diharapkan memberikan dampak positif pada kepuasan konsumen.

$\mathrm{H}_{2}$ : Promosi berpengaruh positif dan signifikan terhadap kepuasan konsumen.

Penelitian yang dilakukan oleh Panjaitan (2016) Berdasarkan hasil uji F dapat diketahui bahwa kualitas pelayanan secara simultan berpengaruh signifikan terhadap kepuasan pelanggan. Selain itu penelitian yang dilakukan oleh Wijayanto (2015) kualitas pelayanan berpengaruh positif dan signifikan terhadap kepuasan konsumen dimana semakin tinggi kualitas pelayanan masing-masing dimensi maka kepuasan nasabah semakin meningkat.

Hafeez and Muhammad (2012) menunjukkan bahwa terdapat pengaruh yang positif dan signifikan antara kualitas pelayanan terhadap kepuasan pelanggan. Penelitian yang dilakukan oleh Shoki et al. (2012) mengatakan bahwa kualitas pelayanan berpengaruh positif dan signifikan terhadap kepuasan pelanggan. Kheng et al. (2010) juga menyebutkan kualitas pelayanan berpengaruh positif terhadap kepuasan pelanggan.

$\mathrm{H}_{3}$ : Kualitas pelayanan berpengaruh positif dan signifikan terhadap kepuasan 


\section{konsumen}

Menurut penelitian Wijayanto (2015) and Jeanne (2012) kepuasan berpengaruh positif dan signifikan terhadap loyalitas konsumen. Menurut pendapat Montolalu (2013) dan Setiawan \& Sayuti (2017) kepuasan pelanggan berpengaruh positif dan signifikan terhadap loyalitas pelanggan. Peneltian yang dilakukan oleh Suwarni (2011) kepuasan konsumen berpengaruh positif dan signifikan terhadap loyalitas konsumen.

$\mathrm{H}_{4}$ : Kepuasan Konsumen berpengaruh positif dan signifikan terhadap loyalitas konsumen.

\section{METODE PENELITIAN}

Objek penelitian ini adalah pengaruh persepsi harga (X1) terhadap kepuasan konsumen (M), pengaruh promosi (X2) terhadap kepuasan konsumen (M), pengaruh kualitas pelayanan (X3) terhadap kepuasan konsumen (M), serta pengaruh kepuasan konsumen (M) terhadap loyalitas konsumen (Y1) khsusnya pada pengguna jasa UberX di Kota Denpasar.

Menurut Sugiyono (2010:118) sampel adalah bagian dari jumlah dan karakteristik yang dimiliki oleh populasi tersebut. Apabila peneliti melakukan penelitian terhadap populasi yang besar, sementara peneliti ingin meneliti tentang populasi tersebut dan peneliti memeiliki keterbatasan dana, tenaga dan waktu, maka peneliti menggunakan teknik pengambilan sampel, sehingga generalisasi kepada populasi yang diteliti. Makna sampel yang diambil dapat mewakili atau representatif bagi populasi tersebut.

Populasi yang digunakan dalam penelenitian ini adalah populasi pengguna jasa transportasi online UberX di Kota Denpasar. Besarnya jumlah sampel yang 
I Made Adi Juniantara, Pengaruh Persepsi Harga, Promosi...

harus diambil dari populasi dalam suatu kegiatan penelitian sangat tergantung dari keadaan populasi itu sendiri, semakin homogen keadaan populasinya maka jumlah sampel semakin sedikit, begitu juga sebaliknya, untuk memperoleh hasil yang baik ukuran sampel responden yang diambil untuk mengisi kuesioner dapat ditentukan paling sedikit 5-10 kali jumlah indikator dari setiap variabel yang diteliti. Jumlah indikator dalam penelitian ini sebanyak 18, sehingga jumlah dari sampel responden yang akan diuji di dapat dari hasil perhitungan berikut :

$$
\begin{aligned}
\text { Jumlah Responden } & =19 \times 7 \\
& =19 \text { indikator } \times 7 \\
& =133 \text { responden }
\end{aligned}
$$

Dipilihnya 133 responden karena dalam penelitian ini menggunakan metode path analysis dimana dalam metode tersebut minimal harus menggunakan 100 sampel. Dan di dalam penelitian ini terdapat 19 indikator di dalam masingmasing variable penelitian ini. Metode penentuan sampel yang digunakan dalam penelitian ini adalah Nonprobability Sampling.

Data kualitatif adalah data yang dinyatakan dalam bentuk kata, kalimat, dan skema (Sugiyono, 2012:13) seperti gambaran umum tentang harga, promosi dan kualitas pelayanan terhadap kepuasan konsumen dan dampaknya terhadap loyalitas konsumen serta penilaian responden terhadap pertanyaan-pertanyaan yang diajukan dalam kuesioner. Data Kuantitatif adalah data dalam bentuk angka yang dapat dinyatakan dan diukur dengan satuan hitung (Sugiyono, 2012:13). Data kuantitatiif dalam penelitian ini yaitu jumlah responden dan skor jawaban kuesioner. Jenis data dalam penelitian ini adalah data primer. Menurut Sugiyono (2012:308) data primer adalah data yang didapat dari sumbernya langsung dengan cara wawancara atau pengisian kuesioner oleh responden yang merupakan 
pengguna UberX di Kota Denpasar. Data fisik ini merupakan data yang di dapatkan dari dokumentasi berupa buku, catatan yang berhubungan dengan masalah yang diteliti. Dalam penelitian ini menggunakan data sekunder yang berupa jurnal, skripsi, buku-buku, artikel, publikasi perusahaan dan majalah yang berhubungan dengan penelitian.

Dalam penelitian ini teknik analisis data yang digunakan adalah teknik analisis jalur. Analisis jalur digunakan untuk menentukan pola hubungan antara tiga atau lebih dan tidak dapat digunakan untuk mengkonfirmasi dan menolak hipotesis, (Eka Aprilsya 2016).

\section{HASIL PENELITIAN DAN PEMBAHASAN}

Jumlah responden yang digunakan dalam penelitian ini adalah 133 orang Responden yang telah memberi tanggapan pada kuesioner penelitian ini telah memenuhi kriteria-kriteria yang telah ditetapkan dalam kriteria responden penelitian yaitu berdomisili Di Kota Denpasar, telah berusia 18 tahun atau setidaknya telah menyelesaikan pendidikan SMA dan pernah menggunakan UberX serta memiliki Aplikasi Uber. Total kuesioner yang diterima adalah 145 yang disebar secara online maupun diberikan langsung kepada responden.

Kuesioner online yang memenuhi kriteria berjumlah 83 dari total 95 responden dan yang diberikan secara langsung berjumlah 50 dari total 53 responden yang mengirimkan jawaban dengan demikian jumlah kuesioner yang datanya diolah adalah sebanyak 133 dengan kata lain anggota sampel adalah 133 orang. Adapun karakteristik dari responden disajikan pada Tabel 1. 
Tabel 1.

Profil Responden

\begin{tabular}{|c|c|c|c|c|}
\hline No & Variabel & Klasifikasi & Jumlah (Orang) & Presentase (\%) \\
\hline 1 & Jenis Kelamin & $\begin{array}{l}\text { Laki - Laki } \\
\text { Perempuan }\end{array}$ & $\begin{array}{l}69 \\
64\end{array}$ & $\begin{array}{l}51,88 \\
48,12\end{array}$ \\
\hline \multirow{3}{*}{2} & Jumlah & & 133 & 100 \\
\hline & Usia (Tahun) & $\begin{array}{l}18-20 \\
21-25 \\
26-35\end{array}$ & $\begin{array}{c}15 \\
111 \\
7\end{array}$ & $\begin{array}{c}11,28 \\
83,46 \\
5,26\end{array}$ \\
\hline & Jumlah & & 133 & 100 \\
\hline 3 & $\begin{array}{l}\text { Pendidikan } \\
\text { Terakhir }\end{array}$ & $\begin{array}{l}\text { SMA/Sederajat } \\
\text { Sarjana }\end{array}$ & 133 & 100 \\
\hline \multirow{3}{*}{4} & Jumlah & & 133 & 100 \\
\hline & Pekerjaan & $\begin{array}{c}\text { Mahasiswa } \\
\text { PNS/Pegawai } \\
\text { Pegawai Swasta } \\
\text { Wiraswasta }\end{array}$ & $\begin{array}{c}96 \\
26 \\
8 \\
3\end{array}$ & $\begin{array}{c}71,18 \\
19,55 \\
6,02 \\
2,26\end{array}$ \\
\hline & Jumlah & & 133 & 100 \\
\hline
\end{tabular}

Sumber: Data diolah, 2018

Berdasarkan Tabel 1 menunjukan bahwa pengguna UberX yang berdomisili di Kota Denpasar merupakan seluruh responden dengan jenis kelamin yang berbeda memiliki angka yang relative hampir sama. Pengguna UberX dominan yang berusia 21-25 tahun, hal ini di hubungkan dengan usia yang sedang produktif pada saat usia tersebut. Berdasarkan variabel tingkat pendidikan, didominasi oleh responden dengan pendidikan terakhir SMA atau Sederajat. Hal ini menunjukan bahwa pengguna UberX di Kota Denpasar didominasi penduduk pada tingkat pendidikan SMA atau sederajat sehingga pengguna UberX juga 
dominan dari kalangan Pelajar/Mahasiswa yang menggunakan UberX untuk pergi ke sekolah atau ke kampus.

Perhitungan koefisien path dilakukan dengan analisis regresi melalui software SPSS 18.0 for windows, diperoleh hasil yang ditunjukan pada Tabel 2.

Tabel 2.

Hasil Analisis Jalur Persamaan Regresi 1

\begin{tabular}{|c|c|c|c|c|c|}
\hline \multirow[t]{2}{*}{ Model } & \multicolumn{2}{|c|}{$\begin{array}{l}\text { Unstandardized } \\
\text { Coefficients }\end{array}$} & \multirow{2}{*}{$\begin{array}{c}\text { Standardized } \\
\text { Coefficients } \\
\text { Beta }\end{array}$} & \multirow[t]{2}{*}{$\mathbf{T}$} & \multirow[t]{2}{*}{ Sig. } \\
\hline & B & Std.Error & & & \\
\hline 1 (Constant) Persepsi & -1.097 & .865 & & -1.268 & .207 \\
\hline harga & .165 & .058 & .156 & 2.823 & .006 \\
\hline Promosi & .240 & .065 & .206 & 3.701 & .000 \\
\hline Kualitas pel & .555 & .052 & .625 & 10.663 & .000 \\
\hline R1 Square & & & & & 0,754 \\
\hline F Statistik & & & & & 132,079 \\
\hline Signifikansi & & & & & 0,000 \\
\hline
\end{tabular}

Sumber : Data diolah, 2018

Berdasarkan hasil analisis jalur substruktur 1 seperti yang disajikan pada Tabel 2, maka persamaan strukturalnya adalah sebagai berikut :

$$
\begin{gathered}
\mathrm{Y} 1=\beta_{1} \mathrm{X}+\beta_{2} \mathrm{X}+\beta_{\mathrm{y}} \mathrm{X}+\varepsilon_{1} \ldots \ldots \ldots \\
\mathrm{Y} 1=0,156 \mathrm{X}+0,206 \mathrm{X}+0,625 \mathrm{X}+\varepsilon_{1}
\end{gathered}
$$

Nilai $\beta_{1}$ adalah sebesar 0,156 memiliki arti bahwa Persepsi Harga berpengaruh positif terhadap Kepuasan Konsumen, Nilai $\beta_{2}$ adalah sebesar 0,206 memiliki arti bahwa Promosi berpengaruh positif terhadap Kepuasan Konsumen dan Nilai $\beta_{\mathrm{a}}$ adalah sebesar 0,625 memiliki arti bahwa Kualitas Pelayanan berpengaruh positif terhadap Kepuasan Konsumen dengan kata lain jika faktor Persepsi Harga, Promosi dan Kualitas Pelayanan meningkat maka akan mengakibatkan peningkatan pada Kepuasan Konsumen UberX di Kota Denpasar sebesar 0,156 (Persepsi harga), 0,206 (Promosi) dan 0,625 (Kualitas pelayanan). 
Tabel 3.

Hasil Analisis Jalur Persamaan Regresi 2

\begin{tabular}{|c|c|c|c|c|c|}
\hline \multirow[t]{2}{*}{ Model } & \multicolumn{2}{|c|}{$\begin{array}{l}\text { Unstandardized } \\
\text { Coefficients }\end{array}$} & \multirow{2}{*}{$\begin{array}{c}\text { Standardized } \\
\text { Coefficients } \\
\text { Beta } \\
\end{array}$} & \multirow[t]{2}{*}{$\mathbf{T}$} & \multirow[t]{2}{*}{ Sig. } \\
\hline & B & Std.Error & & & \\
\hline 1 (Constant) Kepuasan & 1.630 & .603 & & 2.703 & .008 \\
\hline Konsumen & .628 & .038 & .821 & 16.432 & .000 \\
\hline R1 Square & & & & & 0,673 \\
\hline F Statistik & & & & & 269.997 \\
\hline Signifikansi & & & & & 0,000 \\
\hline
\end{tabular}

Sumber: Data diolah, 2018

Berdasarkan hasil analisis jalur substruktur 2 seperti yang disajikan pada

Tabel 3, maka persamaan strukturalnya adalah sebagai berikut :

$$
\begin{gathered}
\mathrm{Y} 2=\beta_{1} \mathrm{Y} 1+\varepsilon_{2} \ldots \\
\mathrm{Y} 2=0,821 \mathrm{Y} 1+\varepsilon_{2}
\end{gathered}
$$

Berdasarkan persamaan tersebut maka dapat disimpulkan bahwa nilai $\beta_{1}$ adalah sebesar 0,821 memiliki arti bahwa Kepuasan Konsumen berpengaruh positif terhadap Loyalitas Konsumen, dengan kata lain jika faktor Kepuasan Konsumen meningkat maka akan mengakibatkan peningkatan pada Loyalitas Konsumen UberX di Kota Denpasar sebesar 0,821.

Berdasarkan hasil analisis pengaruh Persepsi Harga terhadap Kepuasan Konsumen diperoleh nilai Sig. $\mathrm{t}$ sebesar 0,006 dengan nilai koefisien beta 0,156. Nilai Sig. t 0,006 $<0,05$ mengindikasikan bahwa $\mathrm{H}_{0}$ ditolak dan $\mathrm{H}_{1}$ diterima. Hasil ini mempunyai arti bahwa Persepsi Harga berpengaruh positif dan signifikan terhadap Kepuasan konsumen.

Berdasarkan hasil analisis pengaruh Promosi terhadap Kepuasan Konsumen diperoleh nilai Sig. $\mathrm{t}$ sebesar 0,000 dengan nilai koefisien beta 0,206. Nilai Sig. $\mathrm{t}$ 
$0,000<0,05$ mengindikasikan bahwa $\mathrm{H}_{0}$ ditolak dan $\mathrm{H}_{1}$ diterima. Hasil ini mempunyai arti bahwa Promosi berpengaruh positif dan signifikan terhadap Kepuasan konsumen.

Berdasarkan hasil analisis pengaruh Kualitas Pelayanan terhadap Kepuasan Konsumen diperoleh nilai Sig. $\mathrm{t}$ sebesar 0,000 dengan nilai koefisien beta 0,625. Nilai Sig. t 0,000 $<0,05$ mengindikasikan bahwa $\mathrm{H}_{0}$ ditolak dan $\mathrm{H}_{1}$ diterima. Hasil ini mempunyai arti bahwa Kualitas Pelayanan berpengaruh positif dan signifikan terhadap Kepuasan konsumen.

Berdasarkan hasil analisis pengaruh Kepuasan Konsumen terhadap Loyalitas Konsumen diperoleh nilai Sig. t sebesar 0,000 dengan nilai koefisien beta 0,821 . Nilai Sig. t $0,000<0,05$ mengindikasikan bahwa $\mathrm{H}_{0}$ ditolak dan $\mathrm{H}_{1}$ diterima. Hasil ini mempunyai arti bahwa Kepuasan Konsumen berpengaruh positif dan signifikan terhadap Loyalitas Konsumen.

Menguji nilai koefisien determinasi $\left(\mathrm{R}^{2}\right)$ dan variabel error (e) berdasarkan model substruktur 1 dan substruktur 2, maka dapat disusun model diagram jalur akhir. Sebelum menyusun model diagram jalur akhir, terlebih dahulu dihitung nilai standar eror sebagai berikut:

$$
\begin{gathered}
\mathrm{Pe}_{\mathrm{i}}=\sqrt{\sqrt{1-\mathrm{R}^{2}}} \ldots \ldots \ldots \ldots \ldots \ldots \ldots \ldots \ldots \ldots \\
\mathrm{Pe}_{1}=\sqrt{1-R_{1}{ }^{2}}=\sqrt{1-0,754}=0,495 \\
\mathrm{Pe}_{2}=\sqrt{1-R_{2}{ }^{2}}=\sqrt{1-0,673}=0,571
\end{gathered}
$$

Berdasarkan perhitungan pengaruh error (Pei), didapatkan hasil pengaruh error $\left(\mathrm{Pe}_{1}\right)$ sebesar 0,459 dan pengaruh error $\left(\mathrm{Pe}_{2}\right)$ sebesar 0,571. Hasil koefisien determinasi total adalah sebagai berikut:

$$
\begin{aligned}
\mathrm{R}^{2} \mathrm{~m} & =1-\left(\mathrm{Pe}_{1}\right)^{2}\left(\mathrm{Pe}_{2}\right)^{2} \ldots \ldots \\
& =1-(0,495)^{2}(0,571)^{2}
\end{aligned}
$$




$$
\begin{aligned}
& =1-(0,245)(0,326) \\
& =1-0,079=0,921
\end{aligned}
$$

Nilai determinasi total sebesar 0,921 mempunyai arti bahwa sebesar 92,10\% variasi Loyalitas Konsumen dipengaruhi oleh Kepuasan Konsumen, sedangkan sisanya sebesar 7,9\% djelaskan oleh faktor lain yang tidak dimasukkan ke dalam model.

Pengujian hipotesis pada pengaruh Persepsi harga terhadap Kepuasan Konsumen menunjukkan bahwa Persepsi Harga secara signifikan berpengaruh positif terhadap Kepuasan Konsumen. Ini berarti semakin bagus persepsi konsumen terhadap harga maka akan meningkatkan kepuasan konsumen UberX.

Hasil penelitian ini mendukung penelitian dari Suwandi (2015), Hasanah (2012) berpendapat bahwa yang mempengaruhi kepuasan pelanggan secara signifikan adalah persepsi harga. Hal ini juga sejalan dengan penelitian yang dilakukan Hermawan et al. (2017) yang menyatakan persepsi harga berpengaruh positif dan signifikan terhadap kepuasan pelanggan.

Pengujian hipotesis pada pengaruh Promosi terhadap Kepuasan Konsumen menunjukkan bahwa Promosi secara signifikan berpengaruh positif terhadap Kepuasan Konsumen. Ini berarti semakin baik/berkualitas promosi yang diberikan kepada konsumen maka akan meningkatkan kepuasan konsumen UberX.

Hasil penelitian ini mendukung penelitian dari penelitian yang dilakukan oleh Faradina dan Satrio (2016), Tjahjaningsih (2013), Sainy dan Romi (2010) dan Khan et al. (2012) memberikan hasil bahwa terdapat pengaruh positif antara promosi terhadap kepuasan pelanggan. Sehingga semakin tinggi promosi diharapkan memberikan dampak positif pada kepuasan konsumen. 
Pengujian hipotesis pada pengaruh Kualitas Pelayanan terhadap Kepuasan Konsumen menunjukkan bahwa Kualitas Pelayanan secara signifikan berpengaruh positif terhadap Kepuasan Konsumen. Ini berarti semakin baik kualitas pelayanan yang diberikan kepada konsumen maka akan meningkatkan kepuasan konsumen UberX.

Hal ini diperkuat oleh penelitian yang dilakukan Wendha dkk. (2013) dan Setiawan dan Sayuti (2017) yang menyatakan bahwa kualitas pelayanan berpengaruh positif dan signifikan terhadap loyalitas pelanggan maskapai garuda indonesia. Hal serupa diungkapkan oleh Bayuningrat (2013) yang mengungkapkan kualitas pelayanan berpengaruh positif dan signifikan terhadap loyalitas pelanggan jasa transportasi taksi Kota Semarang.

Pengujian hipotesis pada pengaruh Kepuasan Konsumen terhadap Loyalitas Konsumen menunjukkan bahwa Kepuasan Konsumen secara signifikan berpengaruh positif terhadap Loyalitas Konsumen. Ini berarti semakin puas konsumen maka semakin loyal konsumen terhadap jasa UberX.

Hal ini didukung oleh penelitian yang dilakukan oleh Basir et al. (2015) dan Chenet (2011) yang menyatakan kepuasan berpengaruh positif dan signifikan terhadap loyalitas pelanggan jasa transportasi. Penelitian yang dilakukan Jonathan (2013) pada perusahaan travel juga menyatakan bahwa kepuasan berpengaruh positif dan signifikan terhadap loyalitas konsumen.

Secara teoritis, penelitian ini berimplikasi terhadap pengembangan konsep yang berkaitan dengan persepsi harga, promosi, kualitas pelayanan, kepuasan, dan loyalitas pelanggan UberX Kota Denpasar. Penelitian ini memperkaya bukti 
I Made Adi Juniantara, Pengaruh Persepsi Harga, Promosi...

empiris hubungan persepsi harga, promosi, kualitas pelayanan, kepuasan, dan loyalitas pelanggan. Hasil penelitian ini mendukung hasil studi bahwa semakin baik persepsi harga, promosi dan kualitas pelayanan pada UberX maka semakin puas konsumen pada UberX sehingga menjadi loyal terhadap UberX.

Secara praktis penelitian ini memberi beberapa implikasi. Variabel persepsi harga, promosi dan kualitas pelayanan berpengaruh positif dan signifikan terhadap kepuasan dan loyalitas konsumen UberX di Kota Denpasar. Rata-rata skor untuk variabel persepsi harga sebesar 3,93. Ini artinya bahwa persepsi harga terhadap UberX sudah baik, tetapi masih perlu ditingkatkan agar bisa bersaing dengan perusahaan jasa yang menawarkan jasa sejenis baik dengan memberikan penjelasan berupa video viral fasilitas dan keunggulan yang ditawarkan UberX sehigga persepsi konsumen terhadap harga dapat terpenuhi dengan jasa yang diberikan. Untuk variabel promosi sudah cukup dipersepsikan baik oleh konsumen terlihat dari rata-rata skor sebesar 3,85 namun perusahaan harus meningkatkan jumlah promosi agar menarik konsumen, khususnya UberX harus mampu mempertahankan pengguna UberX dengan memberikan promosi berupa potongan harga agar konsumen semakin sering menggunakan UberX. Variabel Kualitas Pelayanan juga sudah cukup dipersepsikan baik oleh konsumen terlihat dari rata-rata skor sebesar 4,07 namun perusahaan harus tetap memberikan pemahaman kepada pengemudi untuk mengetahui bagaimana cara menjadi driver berbintang lima agar pengemudi mampu memberikan kualitas pelayanan yang terbaik kepada konsumen UberX sehingga konsumen tidak berpindah ke produk yang lain. 
Variabel kepuasan secara keseluruhan pelanggan sudah cukup merasa puas terlihat dari rata-rata skor sebesar 3,89. Artinya secara umum pelanggan sudah merasa puas dengan persepsi harga, promosi dan kualitas pelayanan yang diberikan UberX namun ada beberapa indikator yang masih perlu ditingkatkan agar konsumen percaya dengan UberX dan tidak berpindah ke perusahaan penyedia jasa transportasi online lainnya. Dari sisi loyalitas, dapat dilihat pelanggan memiliki loyalitas yang tinggi kepada UberX dengan skor rata-rata sebesar 3,80. Ini mengindikasikan bahwa pelanggan memiliki niat untuk menggunakan UberX secara terus menerus dan mereferensikan UberX kepada orang lain dan memberikan fasilitas yang membuat konsumen merasa puas dan loyal terhadap UberX dan tidak berpindah ke jasa penyedia transportasi online lainnya. Untuk itulah maka pihak manajemen diharapkan mampu mempertahankan indikator-indikator yang sudah dianggap baik oleh pelanggan dan meningkatkan indikator-indikator yang masih dianggap kurang oleh pelanggan UberX.

Penelitian ini masih memiliki beberapa keterbatasan yaitu penelitian dilakukan sebelum akuisisi Grab terhadap Uber pada tanggal 8 April 2018 dan penelitian ini hanya relevant pada saat sebelum akuisisi Grab terhadap Uber.

Ruang lingkup penelitian terbatas pada Wilayah Kota Denpasar dengan jumlah sampel sebanyak 133 orang, sehingga hasil penelitian ini tidak dapat digeneralisasi dalam lingkup yang lebih luas.

Penelitian ini hanya meneliti pengaruh persepsi harga, promosi dan kualitas pelayanan terhadap konsumen dan dampaknya terhadap loyalitas konsumen pada 
I Made Adi Juniantara, Pengaruh Persepsi Harga, Promosi...

UberX, sedangkan masih ada banyak faktor yang mempengaruhi loyalitas pelanggan misalnya brand image dan kualitas produk, sehingga penelitian ini penting untuk dilakukan kembali.

\section{SIMPULAN DAN SARAN}

Berdasarkan pembahasan hasil penelitian yang telah dilakukan, maka dapat disimpulkan bahwa persepsi harga berpengaruh positif dan signifikan terhadap kepuasan. Hal ini berarti apabila UberX mampu memberikan tarif yang sesuai dengan harapan konsumen maka konsumen akan memiliki persepsi positif terhadap tarif UberX di Kota Denpasar akan meningkat.

Promosi berpengaruh positif dan signifikan terhadap kepuasan. Hal ini berarti apabila UberX mampu memberikan promosi yang baik dan berkualitas maka konsumen akan memiliki persepsi positif terhadap Promosi UberX, sehingga tingkat kepuasan konsumen akan semakin meningkat.

Kualitas pelayanan berpengaruh positif dan signifikan terhadap kepuasan. Hal ini berarti jika UberX mampu memberikan kualitas pelayanan yang optimal maka konsumen akan semakin puas dengan UberX.

Kepuasan berpengaruh positif dan signifikan terhadap loyalitas konsumen. Hal ini berarti semakin tinggi tingkat kepuasan konsumen UberX di Kota Denpasar maka semakin tinggi pula tinggat loyalitas konsumen UberX.

Berdasarkan hasil penelitian, pembahsan dan kesimpulan maka saran yang dapat diberikan adalah penelitian ini masih memiliki banyak kekurangan seperti keterbatasan jumlah responden dan masih menggunakan teknis analisis jalur (path analysis). Penelitian selanjutnya diharapkan dapat menyebarkan kuesioner ke 
wilayah yang lebih luas dan data yang diperoleh. Untuk penelitian selanjutnya diharapkan untuk dapat melakukan penelitian dengan menggunakan Variabel yang sama namun pada perusahaan yang berbeda seperti Grab dan Go-Jek.

Manajemen Uber disarankan untuk semakin memperhatikan persepsi harga yang diharapkan oleh konsumen sehingga konsumen bisa mempersepsikan harga dengan manfaat yang diberikan setelah menggunakan UberX dibandingkan dengan perusahaan penyedia jada transportasi berbasis online lainnya. Pihak Uber juga harus memperhatikan dari sisi promosi, khususnya untuk pengguna UberX agar promosi yang diberikan mampu menarik konsumen untuk tetap menggunakan UberX.

Pihak manajemen Uber harus memperhatikan kualitas pelayanan yang diberikan oleh pengemudi dan memberikan pemahaman kepada pengemudi untuk menjadi pengemudi bintang lima sehingga konsumen Uber tidak berpindah ke jasa transportasi online lain. Kepuasan konsumen juga harus diperhatikan agar konsumen mampu percaya dengan fasilitas atau keunggulan yang ditawarkan oleh UberX dibandingkan dengan penyedia jasa lainnya.

\section{REFERENSI}

Alam, Syed Syah and Norjaya Mohd Yasin. 2010. What factors influence online brand trust: evidence from online ticket buyers in Malaysia. Journal of Theoretical and Applied Electronic Commerce Research, 5(3), 77-89.

Alma, B. 2014. Manajemen Pemasaran dan Pemasaran Jasa. Cetakan Keenam. Alfabeta. Bandung.

Arvinia, Herawati, Ari Pradhanawati. dan Reni, Shinta Dewi. 2013. Pengaruh Bauran Pemasaran Ritel terhadap Loyalitas Pelanggan melalui Kepuasan Pelanggan Pada Konsumen Alfamart di Kecamatan Tembalang Semarang. Jurnal Sosial dan Politik, 1(2), 1-9. 
Bhuwana, Made Bagus Rangga dan Ida Bagus Sudiksa. 2013. Pengaruh Kualitas Layanan dan Kepuasan Pelanggan Terhadap Niat Pemakaian Ulang Jasa Service Pada Bengkel Toyota Auto 2000 Denpasar, E-Jurnal Manajemen Universitas Udayana, 2(4), 2302-8912.

Chenet, P. Dagger. and T. S. Sullivan, D.O. 2011. Service Quality, Trust, Commitment and Service Differentiation in Business Relationship. Journal of Services Marketing, 24(5), 336-346.

Endang, Tjahjaningsih. 2013. Pengaruh Citra dan Promosi Terhadap kepuasan Pelanggan Serta Dampaknya Terhadap Loyalitas Pelanggan (Studi Pada Pelanggan Supermarket Carrefour Di Semarang). Jurnal Media Ekonomi dan Manajemen, 28(2), 23-26.

Freddy, Rangkuti. 2006. Measuring Customer Satisfaction. Teknik Mengukur dan Strategi Meningkatkan Kepuasan Pelanggan. Cetakan Ke Tiga PT. Granedia Pustaka Utama. Jakarta.

Ginting, Nembah F. Hartimbul. 2012. Manajemen Pemasaran. Cetakan 2. Bandung. Yrama Widya.

Griffin, W. Ricky dan Eber., J, ronal. 2007. Business. Edisi Kedelapan jilid satu. Erlangga, Jakarta.

Hafeez, Samraz. and Muhammad, Bakhtiar. 2012. The Impact of Service Quality, Customer Satisfaction and Loyalty Programs on Customer's Loyalty: Evidence from Banking Sector of Pakistan. Journal of Marketing, 3(1), 200-209.

Harjanto. 2010. Analisis Pengaruh Harga, Produk, Kebersihan, dan Kualitas Layanan terhadap Kepuasan Pelanggan. Jurnal Manajemen. 3(2), 23-29.

Hermawan, B. Basalamah, S. Djamereng, A. dan Plyriadi, A.2017. Effect of Service Quality and Price Perception on Corporate Image, Customer Satisfaction and Customer Loyalty among Mobile Telecommunication Services Provider. Journal of Management and Social Sciences. 8(1), 6273.

Irawan, Handi. 2008. Indonesia Customer Satisfaction. Jakarta: PT. Alex Media Computindo.

Iwan Kurniawan, Suryono Budi santoso dan Bambang Munas Dwiyanto. 2008. Analisis Faktor-Faktor Yang Mempengaruhi Minat Beli Ulang Produk Serta Dampaknya Terhadap Loyalitas Pelanggan (Studi Kasus Pada Produk Sakatonik Liver Di Kota Semarang). Jurnal Manajemen Pemasaran, 64, 1-14.

Jiang. Pingjun dan Rosenbloom, Bert. 2015. Customer Intention to Return Online: 
Price Perception, Attribute-level Perfomance, and Statisfaction Unfolding Over Time. International Journal of Marketing, 4(1), 20-30.

Jeanne, A.S. 2012. The impact of Service Quality and Perceived Value on Customer Satisfaction and Loyalty in Surabaya City. Journal of Economic and Business. 3(4), 31-32.

Khan, Shahzad et al. 2012. Determinants of Customer Satisfaction in Fast Food Industry. International Journal of Management and Strategy, 3, 35-38.

Kheng, L. Lo. Osman, Mahamad, T. Ramayah, and Rahim, Mosahab. 2010. The Impact of Service Quality on Customer Loyalty: A Study of Banks in Penang, Malaysia. Journal of Marketing, 2, 57-66.

Kotler, Philip \& Keller. 2012. Manajemen Pemasaran. Edisi 12. Jilid 1. Alih Bahasa : Benyamin Molan. Indeks. Jakarta.

Kotler, Philip dan Keller, Kevin Lane. 2009. Manajemen Pemasaran, Benyamin Molan (terjemahan) Marketing Management Edisi Ketiga Belas, Jilid Dua, : Erlangga, Jakarta.

Kurniasih, I. 2012. Pengaruh Harga dan Kualitas Pelayanan Terhadap Loyalitas Pelanggan Melalui Variable Kepuasan (Studi Pada Bengkel AHASS 0002Astra Motor Siliwangi Semarang). Jurnal Administrasi Bisnis, 1(1), 37-40.

Lupiyoadi, R. 2013. Manajemen Pemasaran Jasa. Edisi 3. Salemba Empat. Jakarta.

Montolalu, M. 2013. The Impact of Service Quality and Price to Customer Statisfaction and Customers Loyalty in Swiss-bellhotel Maleosan Manado. Journal EMBA, 1(4), 1491-1497.

Nardiman dan Yasri. 2013. Pengaruh Harga, Promosi dan Kualitas Pelayanan Terhadap Kepuasan dan Dampaknya pada Loyalitas Nasabah Adira Finance di Kecamatan Kinali Kabupaten Pasaman Barat. Jurnal Manajemen Pemasaran, 64, 2.

Olorunniwo, F., Hsu, M.K. and Udo, G.J., 2010. Service Quality, Customer Satisfaction, and Behavior Intentions in The Service Faktory. The Journal of Services Marketing, 20(1), 59-72.

Oosthuizen, Ms. D. and Spowart. 2015. The Relationship Between Perceived Price and Consumers' Purchase Intentions of Private Label Wine Brands. African Journal of Hospitality, Tourism and Leisure, 4(2), 1-17.

Panjaitan. 2016. Pengaruh Kualitas Pelayanan Terhadap Kepuasan Pelanggan Pada Jne Cabang Bandung. Jurnal Manajemen Bisnis. Prodi Administrasi Bisnis, Fakultas Komunikasi dan Bisnis Universitas Telkom, 3(1), 2-12. 
Sainy, Romi. 2010. A Study Of The Effect Of Service Quality On Customer Loyalty In Retail Outlets. Journal Of Management, 2(1), 49-62.

Setiawan, H., dan Sayuti, A. 2017. Effects of Service Quality, Customer Trust and Corporate Image on Customer Satisfaction and Loyalty: An Assessment of Travel Agencies Customer in South Sumatra Indonesia. Journal of Bussiness and Management, 19(3), 31-40.

Setiyaningrum, A. Udaya, Jusuf. Dan Efendi. 2015. Prinsip-Prinsip Pemasaran. Andi Offset. Yogyakarta.

Setiawan, H., dan Sayuti, A. 2017. Effect of Service Quality, Customer Trust, and Corporate Image on Customer Satisfaction and Loyalty an Assessment of Travel Agencies Customer in South Sumatra Indonesia. Journal of Business and Managemen,. 19(3), 31-40.

Shoki, Mohd. Bin Md, Arif. 2012. Relationship Between Customers Perceived Values, Satisfaction and Loyalty of Mobile Phone Users. International journal of Management, 1(2), 126-135.

Suprapti, Sri. 2010. Perilaku Kosumen. Udayana University Press.

Suwarni, Mayasari 2011. Pengaruh Kualitas Produk dan Harga terhadap Loyalitas melalui Kepuasan Konsumen. Jurnal Ekonomi Bisnis Universitas Negeri Malang, 1, 42-46.

Tjiptono, Fandy and Gregorius Chandra. 2011. Service Quality Satisfaction. CV. Andi. Yogyakarta.

Tjahjaningsih. 2013. Pengaruh Citra dan Promosi Terhadap Kepuasan Pelanggan Serta Dampaknya Terhadap Loyalitas Pelanggan (Studi Pada Pelanggan Supermarket Carrefour di Semarang). Jurnal Manajemen Universitas Stikubank,4(3), 23-28.

Widjajanti, Kesi Dan Nina Ernawati. 2012. Analisis Pengaruh Kualitas Pelayanan Terhadap Kepuasan Pelanggan Di Warnet Usm. Jurnal Dinamika Sosbud, 14(1), 63-71

Wijayanto, Kusuma. 2015. Pengaruh Kualitas Pelayanan terhadap Kepuasan dan Loyalitas Nasabah Bank . Jurnal Ekonomi Manajemen Sumber Daya, 17(1), 13-16. 